\title{
Synthesis and Biocompatibility of an Experimental Glass Ionomer Cement Prepared by a Non-Hydrolytic Sol-Gel Method
}

\author{
Lucas da Fonseca Roberti GARCIA ${ }^{1}$ \\ Fernanda de Carvalho Panzeri PIRES-DE-SOUZA ${ }^{1}$ \\ Juliana Mazzoneto TEÓFILO ${ }^{1}$ \\ Alexandre CESTARI ${ }^{2}$ \\ Paulo Sergio CALEFI ${ }^{2}$ \\ Katia Jorge CIUFFI ${ }^{2}$ \\ Eduardo José NASSAR ${ }^{2}$ \\ ${ }^{1}$ Department of Dental Materials and Prosthodontics, Ribeirão Preto Dental School, \\ University of São Paulo, Ribeirão Preto, SP, Brazil \\ ${ }^{2}$ Department of Chemistry, Franca School of Chemistry, University of Franca, Franca, SP, Brazil
}

\begin{abstract}
The aims of this study were to demonstrate the synthesis of an experimental glass ionomer cement (GIC) by the non-hydrolytic sol-gel method and to evaluate its biocompatibility in comparison to a conventional glass ionomer cement (Vidrion R). Four polyethylene tubes containing the tested cements were implanted in the dorsal region of 15 rats, as follows: GI - experimental GIC and GII - conventional GIC. The external tube walls was considered the control group (CG). The rats were sacrificed 7, 21 and 42 days after implant placement for histopathological analysis. A four-point (I-IV) scoring system was used to graduate the inflammatory reaction. Regarding the experimental GIC sintherization, thermogravimetric and x-ray diffraction analysis demonstrated vitreous material formation at $110^{\circ} \mathrm{C}$ by the sol-gel method. For biocompatibility test, results showed a moderate chronic inflammatory reaction for GI (III), severe for GII (IV) and mild for CG (II) at 7 days. After 21 days, GI presented a mild reaction (II); GII, moderate (III) and CG, mild (II). At 42 days, GI showed a mild/absent inflammatory reaction (II to I), similar to GII (II to I). CG presented absence of chronic inflammatory reaction (I). It was concluded that the experimental GIC presented mild/absent tissue reaction after 42 days, being biocompatible when tested in the connective tissue of rats.
\end{abstract}

Key Words: glass ionomer cement, sol-gel synthesis, biocompatibility, dental materials.

\section{INTRODUCTION}

Since glass ionomer cement (GIC) was introduced into Dentistry in the early 1970 's by Wilson and Kent (1), it has been widely due to its capacity to adhere to dental structures even without previous surface treatment, its coefficient of thermal expansion and modulus of elasticity similar to dentin, its fluoride releasing capacity, which aids preventing and inhibiting caries recurrence and remineralizing the dental structure, and its biocompatibility (2-4). Furthermore, in its original formulation, GIC allowed a series of modifications to be made to its composition, which significantly improved its physicochemical properties (4).

The GIC powder is a calcium fluoroaluminosilicate glass, to which other components, such as lanthanum, strontium, barium and zinc oxide, have been added, the vitreous particles being susceptible to acid attack. The acid used in the majority of contemporary cements is an aqueous solution of polyacrylic and tartaric acid. When mixed with the powder, a paste is formed in which the acid reacts with the glass particles, and calcium, aluminum, sodium and fluoride ions are released into the aqueous medium $(1,4)$. The acid groups of the organic polyacrylic acid chains, for example, react with the glass powder, breaking the Al-O-Si bonds, releasing

Correspondence: Profa. Dra. Fernanda de Carvalho Panzeri Pires-de-Souza, Faculdade de Odontologia de Ribeirão Preto, Departamento de Materiais Dentários e Prótese, FORP-USP, Avenida do Café, S/N, Monte Alegre, 14040-904 Ribeirão Preto, SP, Brasil. Tel: +55-16-3602-3973. Fax: +55-163633-0999. e-mail: ferpanzeri@forp.usp.br 
calcium and aluminum ions into the aqueous medium. Initially the calcium ions, and later the aluminum ions form crosslinks between the organic chains forming carboxylate, converting the carboxylate acid group into salt, forming the cement. The sodium and fluoride ions do not participate in crosslinks, and some of these sodium ions may substitute the hydrogen ions from the carboxylic groups, while other ions and vitreous particles covered with silicon gel are dispersed within the cement that has already become set $(1,4)$.

Based on the possibility of modifying its composition, an experimental GIC was developed by means of the nonhydrolytic sol-gel method, with the aim of improving its biocompatibility and physicochemical properties. The non-hydrolytic sol-gel method used for the synthesis of the glass powder allows the material to be obtained at temperatures close to $110^{\circ} \mathrm{C}$, differently from the industrial method currently used for the fusion of oxides, which uses temperatures between 1100 to $1500^{\circ} \mathrm{C}(5)$. The use of high temperatures, particularly on an industrial scale, consumes a huge quantity of energy, since the oxide links need to be ruptured and then formed again for the synthesis of glass. This makes production cost higher than that of the sol-gel method (5). However, for biological applications, new materials need to be evaluated with regard to biocompatibility, before their application in human beings.

The aims of this study were to demonstrate the nonhydrolytic sol-gel synthesis method of this new material and to evaluate its biocompatibility, in comparison to a conventional GIC, through morphological and morphometric analyses of the reaction caused by these cements in the subcutaneous tissue of rats.

\section{MATERIAL AND METHODS}

\section{Synthesis and Characterization of the Experimental Glass Powder}

The synthesis of fluoroaluminosilicate calcium powder containing sodium and phosphorus was made based on Table 1 .

Initially, silicon and aluminum chlorides were used to substitute the oxides, because the materials were synthesized by the nonhydrolytic sol-gel method. The reagents $\mathrm{AlCl}_{3}, \mathrm{AlF}_{3}, \mathrm{CaF}_{2}, \mathrm{NaF}, \mathrm{SiCl}_{4}$, and $\mathrm{AlPO}_{4}$ in weight percentages of 28.6, 1.6, 15.7, 9.3, 41.9, and 3.8 , respectively, were added to $40 \mathrm{~mL}$ of anhydrous ethanol and $10 \mathrm{~mL}$ of diisopropyl ether, used as oxygen donors. One percent of $\mathrm{EuCl}_{3}$ in weight was added as structural probe. The reaction was kept under reflux and magnetic stirring for $4 \mathrm{~h}$ in inert argon atmosphere. The condenser was placed in a thermostatic bath at $-5^{\circ} \mathrm{C}$. After the reflux, the mixture was cooled and aged overnight in the mother liquor at room temperature, and precipitation continued through aging in the mother liquor. The solvent was then removed under vacuum. The powder was dried for 7 days at $50^{\circ} \mathrm{C}$, resulting in a fine white powder (5).

The material was thermally analyzed using a SDT Q60 simultaneous differential thermal analysis (DTA) and thermogravimetric (TG) analyzer (TG/DSC/DTA) (TA Instruments, Twin Lakes, WI, USA). Analyses started at room temperature $\left(25^{\circ} \mathrm{C}\right)$ and the temperature was raised to $1100^{\circ} \mathrm{C}$ at a heating rate of $20^{\circ} \mathrm{C} / \mathrm{min}$, under a nitrogen flow of $100 \mathrm{~mL} / \mathrm{min}$. The $\mathrm{x}$-ray diffraction measurements were taken at room temperature with a Rigaku Geigerflex D/max-c diffractometer (Rigaku MSC, The Woodlands, TX, USA), using monochromatic $\mathrm{Cu} \mathrm{K} \alpha$ radiation $\left(\lambda=1.54 \mathrm{~A}^{\circ}\right)$ with $2 \theta$ (degree) gamma between $4^{\circ}$ and $80^{\circ}$, with a resolution of 0.05 .

\section{Biocompatibility Test - Subcutaneous Implant}

This study was conducted with approval by the institutional Research Ethics Committee for Animal Experimentation, in accordance with the ethical concepts for use of laboratory animals at all stages of the experiment. Polyethylene tubes were obtained according to the methodology used by Campos-Pinto et al. (6), which an urethral catheter with an internal diameter of $0.8 \mathrm{~mm}$ was sectioned sequentially at 10 $\mathrm{mm}$ intervals. After sectioning, one of the tube ends was sealed with cyanoacrylate ester gel (Super Bonder, Aachen, Germany) to avoid extravasation of material

Table 1. Components used for the synthesis of the experimental glass ionomer powder.

\begin{tabular}{lc}
\hline Components & Mass \% \\
\hline $\mathrm{SiCl}_{4}$ & 41.9 \\
$\mathrm{Al}_{2} \mathrm{O}_{3}$ & 28.6 \\
$\mathrm{AlF}_{3}$ & 1.6 \\
$\mathrm{CaF}_{2}$ & 15.7 \\
$\mathrm{NaF}$ & 9.3 \\
$\mathrm{AlPO}_{4}$ & 3.8 \\
\hline
\end{tabular}


to be tested. The tubes obtained were placed in a metal box and autoclaved at $120^{\circ} \mathrm{C}$ for $20 \mathrm{~min}$.

Vidrion $\mathrm{R}$ was chosen for this study as the conventional GIC $(7,8)$ because it has similar composition to that of the experimental GIC (Table 2), differing only in the method of obtaining the glass powder. In addition, due to its appropriate biological properties, Vidrion R served as a reference material for the tissue reactions promoted by experimental GIC (9).

The powder and the liquid of the tested cements were mixed on a clean and sterile glass plate in accordance with the manufacturer's instructions. The sterile polyethylene tubes were immediately filled with the cements with the aid of a sterile lentulo drill (Dentsply/ Maillefer, Ballaigues, Switzerland), compatible with the internal diameter of the polyethylene tube.

Fifteen young adult male rats (Rattus novergicus, Albinus, Holtzman), weighing between $200 \mathrm{~g}$ and $250 \mathrm{~g}$ were used. The animals were kept in plastic cages $(40 \times 32 \times 17 \mathrm{~cm})$ in a room with controlled climate conditions (12 h light/12 h dark; temperature of $21-25^{\circ} \mathrm{C}$ ), and received balanced chow (Nuvilab, Colombo, PR, Brazil) and water ad libitum. For the subcutaneous implant procedure, the animals were anesthetized with a combination of $10 \%$ ketamine hydrochloride solution (Agener União, Embu-Guaçu, SP, Brazil) $(75 \mathrm{mg} / \mathrm{kg})$ xylazine hydrochloride $(10 \mathrm{mg} / \mathrm{kg})$

Table 2. Tested materials.

\begin{tabular}{|c|c|c|}
\hline GIC & Composition & Manufacturer \\
\hline Experimental & $\begin{array}{l}\text { Powder: Calcium } \\
\text { fluoroaluminosilicate containing } \\
\text { phosphorous } \\
\text { and sodium } \\
\text { Liquid: Tartaric acid, } \\
\text { polyacrylic acid, } \\
\text { distilled water }\end{array}$ & $\begin{array}{l}\text { Sol-gel method; } \\
\text { Chemical } \\
\text { Laboratory, } \\
\text { Unifran, Franca, } \\
\text { SP, Brazil }\end{array}$ \\
\hline $\begin{array}{l}\text { Conventional } \\
\text { (Vidrion R) }\end{array}$ & $\begin{array}{l}\text { Powder: Sodium fluorosilicate, } \\
\text { calcium, aluminum, } \\
\text { barium sulphate, pigments. } \\
\text { Liquid: Tartaric acid, } \\
\text { polyacrylic acid, } \\
\text { distilled water. }\end{array}$ & $\begin{array}{c}\text { SS White, Prima } \\
\text { Dental Group, } \\
\text { Gloucester, UK }\end{array}$ \\
\hline
\end{tabular}

(Dopaser; Laboratórios Calier S/A, Barcelona, Spain), administered intraperitoneally.

Each animal received 4 tubes with the tested materials, 2 in the scapular region and 2 in the pelvic region (one on the right side and the other on the left side), each pair representing one group (GI - experimental GIC and GII - conventional GIC). The external tube walls was considered the control group (CG). After 7, 21, and 42 days, the rats were killed by anesthetic overdose and the tubes removed for histological analysis. Thus, there were 5 rats for each studied period, totalizing, 10 samples for each experimental group in each of the periods $(\mathrm{n}=10)$. The samples were fixed in $10 \%$ buffered formalin solution for $24 \mathrm{~h}$ and processed for conventional histopathological examination. The connective tissue adjacent to the open end of each tube was sectioned at a microtome setting of $5 \mu \mathrm{m}$. The sections were selected from semi-serial cuts, from which 10 were discarded and 5 were selected and stained with hematoxylin and eosin. Histopathological analyses were performed under a light microscope (Carl Zeiss, Oberkachen, Germany) at 100× and $200 \times$ magnifications, based on the tissue responses stimulated by the tested cements and the control group. Quantitative and qualitative analyses were made in 6 separate areas of $0.021 \mathrm{~mm}^{2}$ inside the fibrous capsule, previously determined, 3 being close to the open end of the polyethylene tube ( 1 central and 2 peripheral), 2 in the intermediate portion of the capsule (at its edges), and 1 in the farthest portion of the polyethylene tube (at the sealed end of the capsule).

The histopathological events evaluated in the test were: inflammatory infiltrate (polymorphonuclear cells and mononuclear cells), capacity of cellularity and vascularization (fibroblasts and blood vessels) and macrophage activity (macrophage and giant inflammatory cells) (10). A score was used to quantify the presence or absence of these events, as follows: $(-)$ absent, (+) mild, $(++)$ moderate and $(+++)$ intense. According to these events, a grade ranging from I to IV (11) was used to graduate the inflammatory reaction: Grade I - diffuse chronic inflammatory cells (no inflammation); Grade II - presence of inflammatory cells and collagen fiber deposits (mild); 
Grade III - dense infiltration of inflammatory cells, tissue edema and vascular congestion (moderate); Grade IV high infiltration of acute and chronic inflammatory cells, extensive edematous areas and vascular congestion, with fibrin deposits (severe). The amplitude of the fibrous capsule $(\mu \mathrm{m})$ was measured using the software AxioVision (Carl Zeiss).

Once the various components of the histopathological events were quantified, the data of the fibrous capsule amplitude were subjected to statistical analysis. The Kolmogorov-Smirnov test was used to test for a normal distribution, and then, a two-way ANOVA was performed to evaluate the different periods of analysis and the cements. The Bonferroni test was also performed for multiple comparisons $(\mathrm{p}<0.05)$.

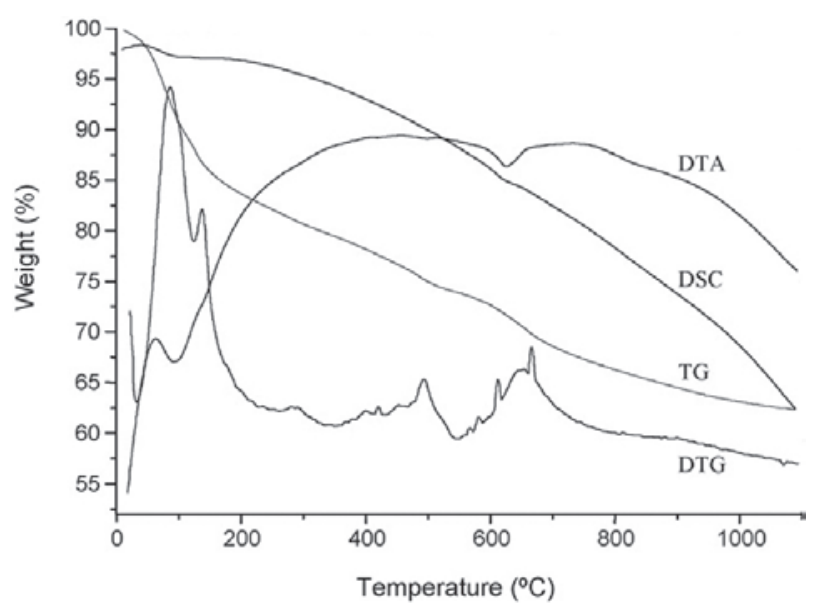

Figure 1. Thermal analysis of the experimental GIC powder.

\section{RESULTS}

\section{Synthesis and Characterization of the Experimental GIC Powder}

The thermogravimetric analysis of the GIC powder shows evidence of a mass loss of $20 \%$ at $325^{\circ} \mathrm{C}$, attributed to volatilization of the solvent (ethanol) and by products of the reaction (alkyl halides). The total loss up to $1100^{\circ} \mathrm{C}$ amounted to $38 \%$ of the initial mass. Differential scanning calorimetry (DSC) and differential thermal analysis techniques revealed an exothermic peak close to $620^{\circ} \mathrm{C}$, attributed to the glass transition (TG) of the material (Fig. 1).

From the x-ray diffractogram, it was possible

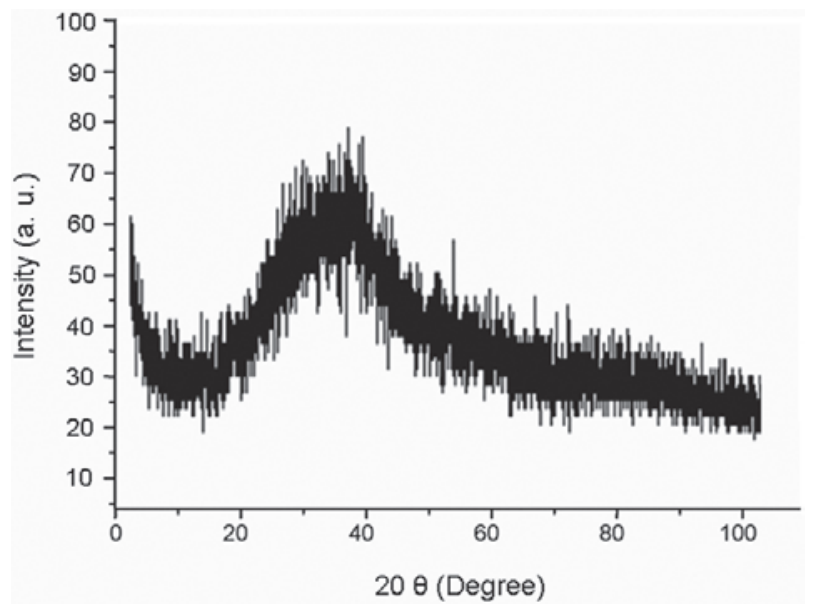

Figure 2. X-ray diffractogram of the experimental GIC powder.

Table 3. Summary of the data obtained for the histopathological events observed in each group at the different periods of study.

\begin{tabular}{|c|c|c|c|c|c|c|c|c|c|}
\hline \multirow{2}{*}{$\begin{array}{l}\text { Histopathological } \\
\text { Events }\end{array}$} & \multicolumn{3}{|c|}{7 days } & \multicolumn{3}{|c|}{21 days } & \multicolumn{3}{|c|}{42 days } \\
\hline & GI & GII & $\mathrm{CG}$ & GI & GII & $\mathrm{CG}$ & GI & GII & $\mathrm{CG}$ \\
\hline Polymorphonuclear & ++ & ++ & + & + & + & + & - & - & - \\
\hline Mononuclear & ++ & +++ & + & + & + & + & - & - & - \\
\hline Fibroblasts & ++ & ++ & + & + & + & + & + & + & + \\
\hline Blood vessels & ++ & +++ & ++ & ++ & + & + & + & + & - \\
\hline Macrophage & + & ++ & + & - & + & - & - & - & - \\
\hline Giant inflammatory cells & + & + & + & - & - & - & - & - & - \\
\hline
\end{tabular}

Score: (-) absent; $(+)$ slight; $(++)$ moderate; $(+++)$ intense. 
to observe a diffraction halo, between approximately 12 and 40 degrees, being characteristic of vitreous material, which proved that the glass was obtained at a temperature of $110^{\circ} \mathrm{C}$ by the sol-gel method (Fig. 2 ). The diffractogram result was very similar to that of commercial glass powders synthesized by high temperature oxide melting methods, confirming that calcium fluoroaluminosilicate glasses containing sodium and phosphorus obtained by the sol-gel method are materials that can be employed in Dentistry, as components of GICs (5).

\section{Qualitative and Quantitative Analysis of the Biocompatibility Test}

The data obtained for all histopathological events assessed in each period of study are presented in Table 3.

\section{Days}

CG: Connective tissue with delicate fibers, highly cellularized with fibroblasts and several blood vessels adjacent to all the analyzed faces was observed (Fig. 3A). A mild chronic inflammatory reaction was observed (Grade II).

GI (Experimental GIC): A layer of cellularized connective tissue with moderate chronic inflammatory reaction, predominantly formed by lymphocytes and blood vessels, was observed. Small areas of necrosis were also noted (Fig. 3B). Few macrophages or foreign body multinucleated giant cells were seen (Grade III).

GII (Conventional GIC): Intense chronic inflammatory reaction, associated with hyperemic blood vessels and macrophages (Fig. 3C). Focus of necrosis area was observed close to the dispersed material (Grade IV).

\section{Days}

CG: This group presented a mild chronic inflammatory reaction in this period (Fig. 4A) (Grade II).

GI (Experimental GIC): In the connective tissue adjacent to the open end of the tube, there was a mild chronic inflammatory reaction, with few lymphocytes and several fibroblasts. Foreign body multinucleated giant cells and macrophages were not observed (Fig. 4B) (Grade II).

GII (Conventional GIC): The connective tissue presented a moderate chronic inflammatory reaction.
Phagocytic activity and rare necrosis areas were also observed (Fig. 4C) (Grade III).

\section{Days}

CG: This group presented no chronic inflammatory reaction in this period (Fig. 5A) (Grade I).

GI (Experimental GIC): Connective tissue with mild to absent chronic inflammatory reaction and residual dispersed cement (Fig. 5B). Absence of necrosis areas or any other changes (Grade II to I).

GII (Conventional GIC): There was a mild to absent chronic inflammatory reaction, without foreign body giant cells or macrophages. Some dispersed material was observed and no necrosis areas or degenerative changes were also observed (Fig. 5C) (Grade II to I).

In the 21- and 42-day periods, the fibrous capsule formed in the region in contact with the tested cement in GII ( $152.7 \mu \mathrm{m})$ was significantly larger when compared with those formed in the GI $(67.2 \mu \mathrm{m})$ and $\mathrm{CG}(110.0 \mu \mathrm{m})(\mathrm{p}<0.05)$. This trend was maintained in the period of 42 days: GI $(64.2 \mu \mathrm{m})$, GII $(91.0 \mu \mathrm{m})$ and CG $(67.1 \mu \mathrm{m})$, though with no statistically significant difference ( $>00.05$ ) among them (Fig. 6). As regards to the inflammatory response, the grades ranged from III (moderate) to I (no inflammation). The tissue elements identified were similar in all the fragments: connective tissue of variable density, with moderate/ mild inflammatory lymphoplasmocitary infiltrate and capsular arrangement at the interface with the material or external tube walls (21- and 42-day periods).

In a general manner, both tested cements caused a mild to absent inflammatory response after 42 days, which is also acceptable from a biological standpoint.

\section{DISCUSSION}

Before introducing a new material to the market, its properties and biocompatibility must be previously studied. From a biological point of view, its irritant potential must be evaluated because eventual toxic components may cause irritation, degeneration or even necrosis of the tissues adjacent to the material (11).

Calcium fluoroaluminosilicate glass containing phosphorus and sodium (Ca-FAlSi) consists of an inorganic polymeric network (mixed oxide) embedded in an aluminum and silicon matrix, comprising an amorphous structure. This material is employed in 
Dentistry as a restorative material designated GIC (1). This restorative cement is produced via an acid-base reaction between the glass (Ca-FAlSi) and an organic polymer acid (e.g., polyacrylic acid), which results in very interesting physical and chemical properties, such
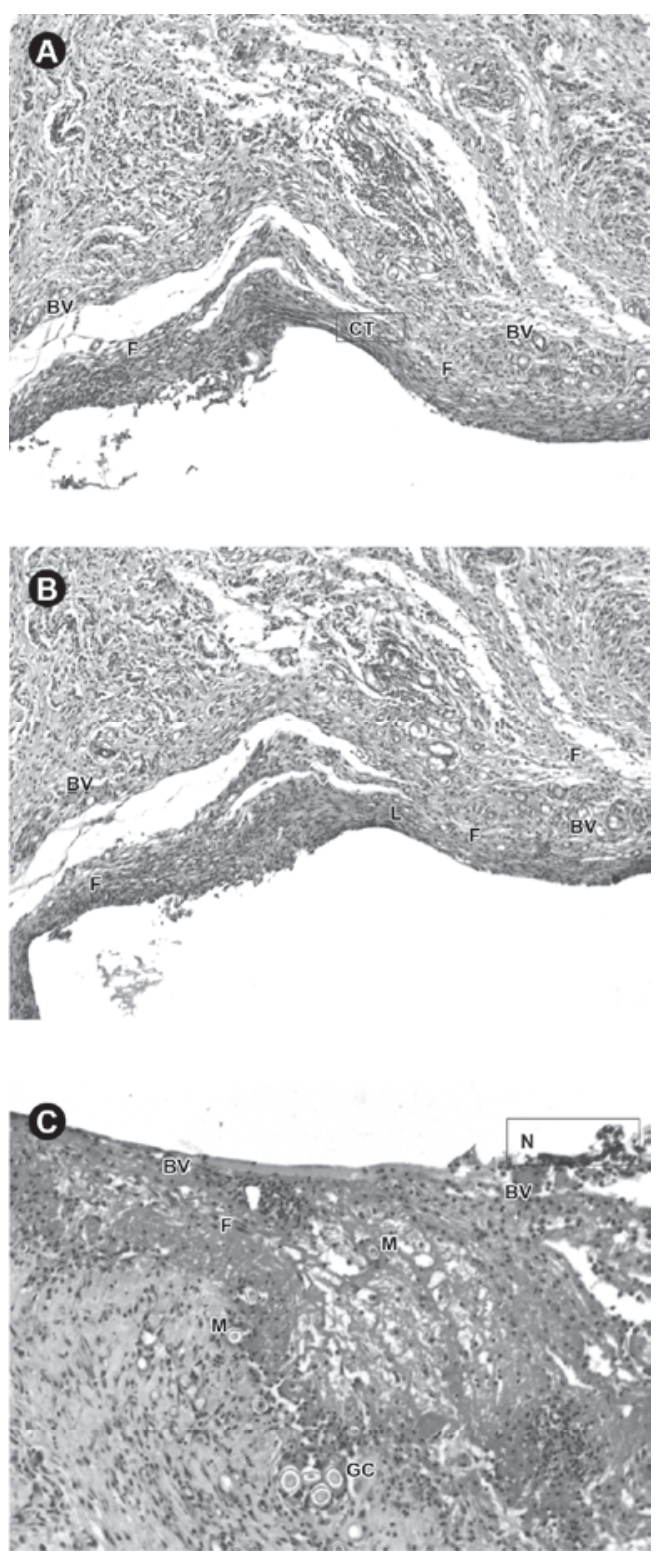

Figure 3. Control Group: A. Mild chronic inflammatory reaction verified after 7 days. Connective tissue with delicate fibers (CT), rich in fibroblasts (F) and blood vessels (BV) adjacent to the polyethylene tube area. GI: B. Moderate chronic inflammatory reaction formed by lymphocytes (L), fibroblasts (F) and blood vessels (BV). GII: C. Intense chronic inflammatory reaction with hyperemic blood vessels (BV), fibroblasts, multinucleated giant cells (GC) and macrophages (M). Necrosis area (N) close to the dispersed material $(\mathrm{HE}$, original magnification $\times 200$ ). as biocompatibility, high adhesiveness compared to other restorative materials, and cariostatic properties owing to the sustained release of fluorides (2-4).

The low temperature synthesis of glass ionomer powder is possible by the non-hydrolytic sol-gel
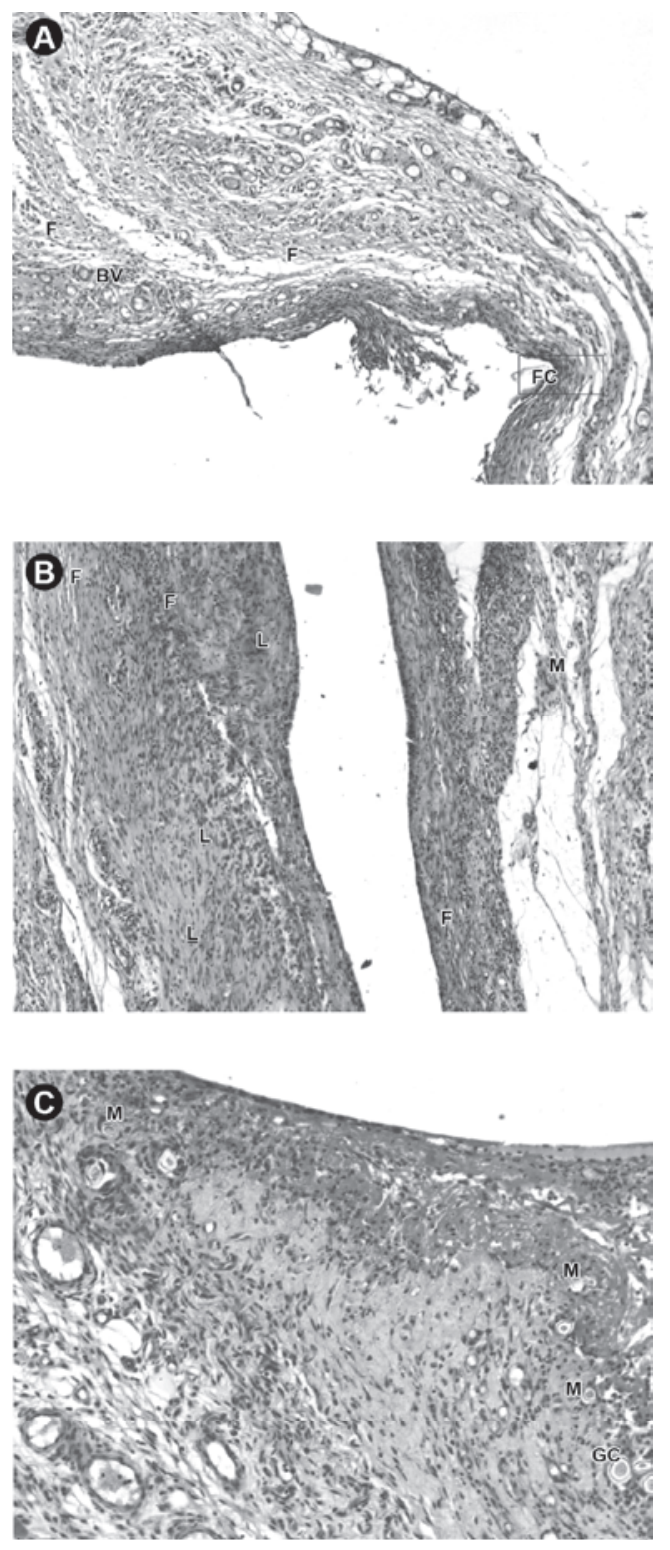

Figure 4. Control Group: A. Mild chronic inflammatory reaction verified after 21 days, with intense fibro-angioblastic proliferation. Presence of fibroblasts (F) and blood vessels (BV). Fibrous capsule (FC). GI: B. Slight chronic inflammatory reaction with lymphocytes (L) and fibroblasts (F). Rare presence of macrophages and absence of foreign body multinucleated giant cells. GII: C. Moderate chronic inflammatory reaction with phagocytic activity (M), foreign body multinucleated giant cells $(\mathrm{GC})$ and rare necrosis areas (HE, original magnification $\times 200$ ). 
method, which significantly diminishes the production cost of the material, and the glass powder used as a component of the experimental GIC was synthesized by this methodology (5).

The basis of the non-hydrolytic sol-gel method
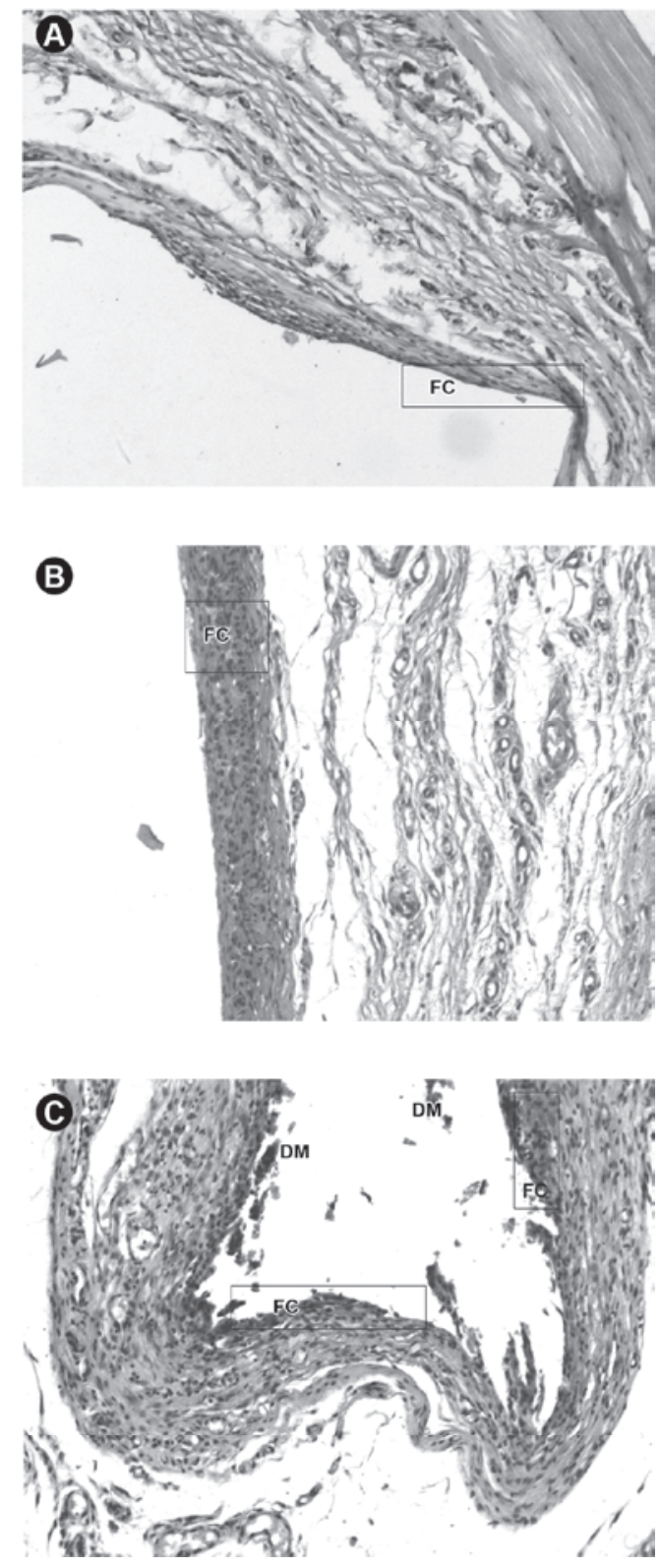

Figure 5. Control Group: A. Absence of chronic inflammatory reaction verified after 42 days. Fibrous capsule (FC). GI: B. Mild to absent chronic inflammatory reaction. Fibrous capsule (FC) adjacent to the polyethylene tube. Absence of necrosis areas (HE, original magnification $\times 200$ ). GI: B. Mild to absent chronic inflammatory reaction without necrosis or degenerative areas. Fibrous capsule (FC) adjacent to the polyethylene tube opening. Dispersal material $(\mathrm{DM})(\mathrm{HE}$, original magnification $\times 100)$. is a condensation reaction between ametallic or semi-metallic halide and a metallic or semi-metallic alkoxide, leading to the formation of an oxide, as well as an alkyl halide as the byproduct. The oxide is then polycondensed, thus forming an inorganic polymer network. The alkoxide can be added to the reaction or produced in situ during the reaction between the halide and an oxygen donor, such as an alcohol or ether. This method enables the preparation of mixed oxides, such as calcium fluoroaluminosilicates, containing sodium and phosphorus in an amorphous structure (5).

To assess biocompatibility of new materials by preliminary in vivo studies, a method commonly used is the subcutaneous implantation of the material to be studied in small animals. Among these animals, the rat (Rattus novergicus, Albinus, Holtzman) is the most frequently used because, in addition to being an experimental model that satisfactorily represents the body of a mammal, it has adequate dimensions to allow easier and safer management and a more accelerated metabolism when compared with other animals, which allows one to obtain relevant results in a short period of time $(12,13)$.

According to the methodology used in this study, implantation of standard polyethylene tubes containing the material for analysis, which only comes into contact with the subcutaneous connective tissue through the tubular opening on one side, as the other side is sealed, allows a comparative analysis among the experimental groups in a standardized manner, without interferences determined by variables of volume and areas of juxtaposition. In turn, the external walls of

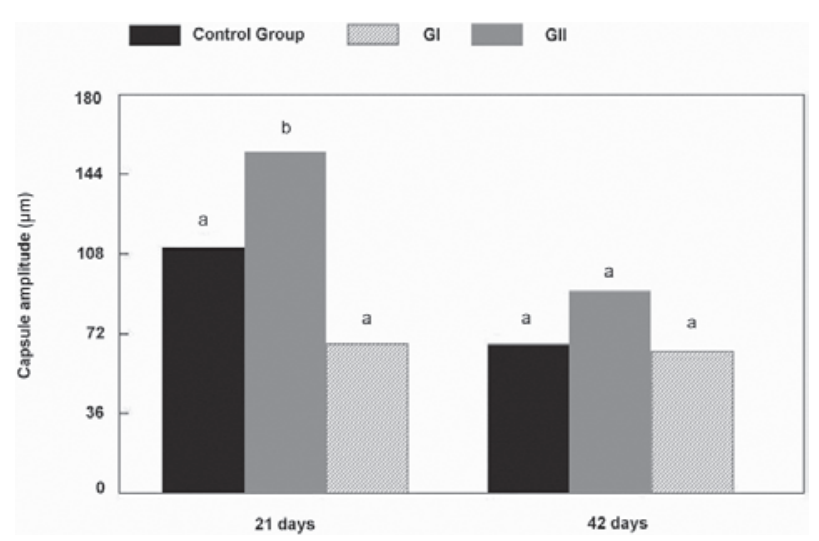

Figure 6. Mean thickness $(\mu \mathrm{m})$ of fibrous capsule at the interface with the tested cements (Groups I and II) and Control Group after periods of 21 and 42 days. Different letters in columns indicate statistically significant difference $(\mathrm{p}<0.05)$. 
the polyethylene tube serve as control due to their low irritating potential, as a basic parameter of the ideal model of reactionary development. Thus, a comparative analysis of the experimental groups could be safely done between the test groups and between them and the control (10,12-14).

The histopathological analysis of the microscopic slides was quantified with the use of indexes for the reactionary phenomena, with a record of the events that occurred in the period of analysis transported in tables prepared for this purpose. When morphological analysis of the tissue reactions is performed by an experiment observer, it makes the results obtained reliable. Not only is morphometry certified with assurance by the counts in strategic areas, but it also corroborates and supports the well defined and directed morphological analysis $(10,12-14)$.

One of the concerns as regards the tissue reaction caused by GIC is related to its disintegration (15) due to humidity in the oral medium, releasing components that may be disseminated inside the dentinal tubules, causing an inflammatory reaction of the pulp tissue (16-18). However, significant results in in vivo tests with GIC have been obtained over the course of the years. Several different formulations of this type of cement have shown adequate biological behavior, allowing the development of tissue repair near the areas of contact with the material in a short period of time (19).

These findings are in agreement with the results obtained in this study because, in general, a reaction of chronic development was observed over the course of the analysis period, showing a reactionary capsule with decreasing amplitude, richly cellularized and vascularized during the initial period of time, to progressive collagenization in the subsequent times, with inflammatory infiltrate with predominance of mononuclear cells (19). In some cases, the presence of polymorphonuclear cells, although reduced in number, conditioned the active reactionary process, and showed less expression in the experimental GIC. This fact was shown to be defined and effective in the initial period, as a natural condition of response to irritation in short periods of time, persistent, and decreasing in medium and final periods in an overall manner, following the sequence of the other events (10-14).

In spite of the positive results found for the experimental GIC in this study, it is worth emphasizing that further research is needed before this material can be indicated for clinical use. The advantages of the non-hydrolytic sol-gel method exceed those of the conventional method for GIC sintherization, because the material is synthesized at lower temperatures, and the resulting product is more homogeneous, with greater stoichiometric control over the reaction. These factors allow better control of the physical-mechanical and biological properties of the cement.

\section{RESUMO}

O objetivo deste estudo foi demonstrar a sinterização pelo método sol-gel não-hidrolítico de um cimento de ionômero de vidro experimental (CIV) e avaliar sua biocompatibilidade em relação a um cimento de ionômero de vidro convencional (Vidrion $\mathrm{R}$ ). Quatro tubos de polietileno contendo os cimentos testados foram implantados no dorso de 15 ratos, da seguinte maneira: GI - CIV Experimental e GII - CIV Convencional. A lateral do tubo foi considerada Grupo Controle. Os ratos foram sacrificados em 7, 21 e 42 dias pós-implantação para análise histopatológica. Uma escala de I a IV foi utilizada como sistema de score para graduar a reação inflamatória. Em relação à sinterização do CIV experimental, as análises termogravométrica e por difração de raio-x demonstraram a formação de material vítreo aos $110^{\circ} \mathrm{C}$ pelo método sol-gel. Para o teste de biocompatibilidade, os resultados mostraram uma reação inflamatória moderada para o GI (III), severa para o GII (IV) e branda para o Grupo Controle (II) aos 7 dias. Após 21 dias, GI apresentou uma reação branda (II); GII, moderada (III) e Grupo Controle, branda (II). Aos 42 dias, GI apresentou uma reação inflamatória branda/ausente (II a I), similar ao GII (II a I). O Grupo Controle demonstrou ausência de reação inflamatória (I). Concluiu-se que o CIV Experimental apresentou reação tecidual branda/ausente após 42 dias, sendo biocompatível quando testado em tecido conjuntivo de ratos.

\section{REFERENCES}

1. Wilson AD, Kent BE. The glass-ionomer cement. A new translucent dental filling material. J Appl Chem Biotechnol 1971;21:3-13.

2. Mickenautsch S, Tyas MJ, Yengopal V, Oliveira LB, Bonecker M. Absence of carious lesions at margins of glass-ionomer cement (GIC) and resin-modified GIC restorations: a systematic review. Eur J Prosthodont Restor Dent 2010;18:139-145.

3. Nakajo K, Imazato S, Takahashi Y, Kiba W, Ebisu S, Takahashi N. Fluoride released from glass-ionomer cement is responsible to inhibit the acid production of caries-related oral streptococci. Dent Mater 2009;25:703-708.

4. Mickenautsch S, Yengopal V, Banerjee A. Pulp response to resin-modified glass ionomer and calcium hydroxide cements in deep cavities: A quantitative systematic review. Dent Mater 2010;26:761-770.

5. Cestari A, Bandeira LC, Calefi PS, Nassar EJ, Ciuffi KJ. Preparation of calcium fluoroaluminosilicate glasses containing sodium and phosphorus by the nonhydrolytic sol-gel method. J Alloys Comp 2009;472:299-306.

6. Campos-Pinto MM, de Oliveira DA, Versiani MA, Silva-Sousa YT, de Sousa-Neto MD, da Cruz Perez DE. Assessment of the biocompatibility of Epiphany root canal sealer in rat subcutaneous tissues. Oral Surg Oral Med Oral Pathol Oral Radiol Endod 
2008; $105: 77-81$

7. da Silva RC, Zuanon AC. Surface roughness of glass ionomer cements indicated for atraumatic restorative treatment (ART). Braz Dent J 2006;17:106-109.

8. Silva RC, Zuanon AC, Esberard RR, Candido MS, Machado JS. In vitro microhardness of glass ionomer cements. J Mater Sci Mater Med 2007;18:139-142.

9. Brentegani LG, Bombonato KF, Carvalho TL. Histological evaluation of the biocompatibility of a glass-ionomer cement in rat alveolus. Biomaterials 1997;18:137-140.

10. Silva RA, Assed S, Nelson-Filho P, Silva LA, Consolaro A. Subcutaneous tissue response of isogenic mice to calcium hydroxide-based pastes with chlorhexidine. Braz Dent J 2009;20:99-106.

11. Shahi S, Rahimi S, Lotfi M, Yavari HR, Gaderian AR. A comparative study of the biocompatibility of three root-end filling materials in rat connective tissue. J Endod 2006;32:776-780.

12. Zmener O. Tissue response to a new methacrylate-based root canal sealer: preliminary observations in the subcutaneous connective tissue of rats. J Endod 2004;30:348-351.

13. Costa CA, Oliveira MF, Giro EMA, Hebling J. Biocompatibility resin-based materials used as pulp-capping agents. Int Endod J 2003;36:831-839.
14. Wang XY, Baba A, Taniguchi K, Hagio M, Miyazaki K. Study on rat subcutaneous reaction to experimental polyurethane elastomers. Dent Mater J 2004;23:512-516.

15. Mount GJ. Buonocore Memorial Lecture. Glass-ionomer cements: past, present and future. Oper Dent 1994;19:82-90.

16. Marshall Jr GW, Marshall SJ, Kinney JH, Balooch M. The dentin substrate: structure and properties related to bonding. J Dent 1997;25:441-458.

17. Devlin AJ, Hatton PV, Brook IM. Dependence of in vitro biocompatibility of ionomeric cements on ion release. J Mater Sci Mater Med 1998;9:737-741.

18. Hurrell-Gillingham KE, Reaney IM, Miller CA, Crawford A, Hatton PV. Devitrification of ionomer glass and its effect on the in vitro biocompatibility of glass ionomer cements. Biomaterials 2003;24:3153-3160.

19. Hurrell-Gillingham K, Reaney IM, Brook I, Hatton PV. In vitro biocompatibility of a novel $\mathrm{Fe}_{2} \mathrm{O}_{3}$ based glass ionomer cement. J Dent 2006;34:533-538.

Accepted November 16, 2010 